EGU Stephan Mueller Special Publication Series, 3, 247-266, 2002

(C) European Geosciences Union 2002

\title{
Neotectonics and its relation to the Mid-Hungarian Mobile Belt
}

\author{
K. D. Lớrincz ${ }^{1}$, F. Horváth ${ }^{2}$, and G. Detzky ${ }^{3}$ \\ ${ }^{1}$ MOL Hungarian Oil and Gas Co., Exploration and Production, H-1039 Budapest, Batthyány u. 45., Hungary \\ ${ }^{2}$ Eötvös Loránd University, Geophysical Department, H-1117 Budapest, Pázmány P. s. 1/c, Hungary \\ ${ }^{3}$ Eötvös Loránd Geophysical Institute of Hungary, H-1145 Budapest, Columbus u. 17-23., Hungary
}

Received: 2 May 2001 - Accepted: 12 June 2002

\begin{abstract}
One of the most significant neotectonic zones of Hungary is the Mid-Hungarian mobile belt, which occupies a key position of the Carpathian-Pannonian region, because it is located at the boundary of two terranes. The study area is situated in this belt at the central part of the Great Hungarian Plain, where on Mesozoic compressional structures two basins of different ages are superimposed: the Paleogene Szolnok flysch trough and the Neogene Pannonian basin.
\end{abstract}

A detailed tectonic analysis was carried out in a $100 \times 60 \mathrm{~km}^{2}$ area on the basis of integrated interpretation of seismic profiles of different penetration (deep, normal, and shallow) and borehole data. The area shows typical features of multi-phase tectonic evolution. The neotectonic phase shows transpressional characters and it is of Quaternary age, most probably with activity until Recent times. This transpression can be interpreted as the late rejuvenation of a wide convergent wrench fault originally formed in the Early Miocene, and first reactivated in the Late Miocene. These three phases of strike-slip faulting have the following characters and magnitudes of displacement. The Early Miocene wide wrench system was right-lateral and it occured along the Mid-Hungarian mobile belt with a few $100 \mathrm{~km}$ horizontal displacement. The Late Miocene activity was leftlateral transpression and the total displacement can be estimated at 5 to $10 \mathrm{~km}$. The horizontal displacement in the Quaternary can be 1 to $5 \mathrm{~km}$ and it is of a left-lateral character. In addition to the multiphase wrench activity distinct compressional and extensional events are characteristic of the area. Large scale thrust faulting occured during the Late Cretaceous as part of the Eoalpine orogenic evolution of the whole Alpine-Carpathian system. The main extensional activity corresponds to the formation of the Pannonian basin primarily in the Middle Miocene, and after an interruption, during the Pliocene.

By analyzing the mapped structures formed during these phases the paleostress field and its temporal variation have been inferred. It can be concluded that the maximum hori-

Correspondence to: K. D. Lőrincz (klorincz@ mol.hu) zontal stress axis shows a $90^{\circ}$ clockwise rotation during the Neogene through Quaternary from NW to NE. The horizontal rotation of stress axes can be related to the shift of termination of subduction along the Carpathian arc. Complete consumption of subductible lithosphere and, hence, onset of continental collision exhibit a progressive time shift along the arc from the Western towards the Eastern Carpathians.

\section{Regional geology}

\subsection{Geological framework of the study area}

The Mid-Hungarian mobile belt is situated on the boundary of two terranes of different Mesozoic origin (Fig. 1). Geological data, comprising a lithological and facies correlations between Alpine and Transdanubian formations (Kázmér and Kovács 1985), suggest a 400 to $500 \mathrm{~km}$ right-lateral horizontal displacement in this belt during the latest Oligocene and Early Miocene. The northwestern unit (Alcapa terrane) was located at the southern margin of the Tethys ocean (Géczy, 1973), and constituted an integral part of the African plate in Jurassic and Cretaceous times (Márton and Márton, 1983). The original position of the southeastern unit (Tisza terrane) at the same time is disputable, but most authors agree that it was associated with the northern margin of the Tethys ocean, as part of the European plate (Balla, 1986; Csontos et al., 1992). A synthesis of all relevant information, particularly field observations, paleostress indicators and paleomagnetic data suggests that the main displacement of the Alcapa unit relative to stable Europe was a lateral extrusion from the Alpine collision zone towards the East, as it was suggested by Ratschbacher et al. (1991a, b). This lateral extrusion culminated during the Early Miocene and was accompanied by about $50^{\circ}$ counterclockwise rotation. In contrast, at about the same time, the Tisza unit underwent a $60^{\circ}$ to $80^{\circ}$ clockwise rotation with small scale lateral translation. The two units became juxtaposed at the end of Early Miocene, and the strongly deformed zone between the two units represents 


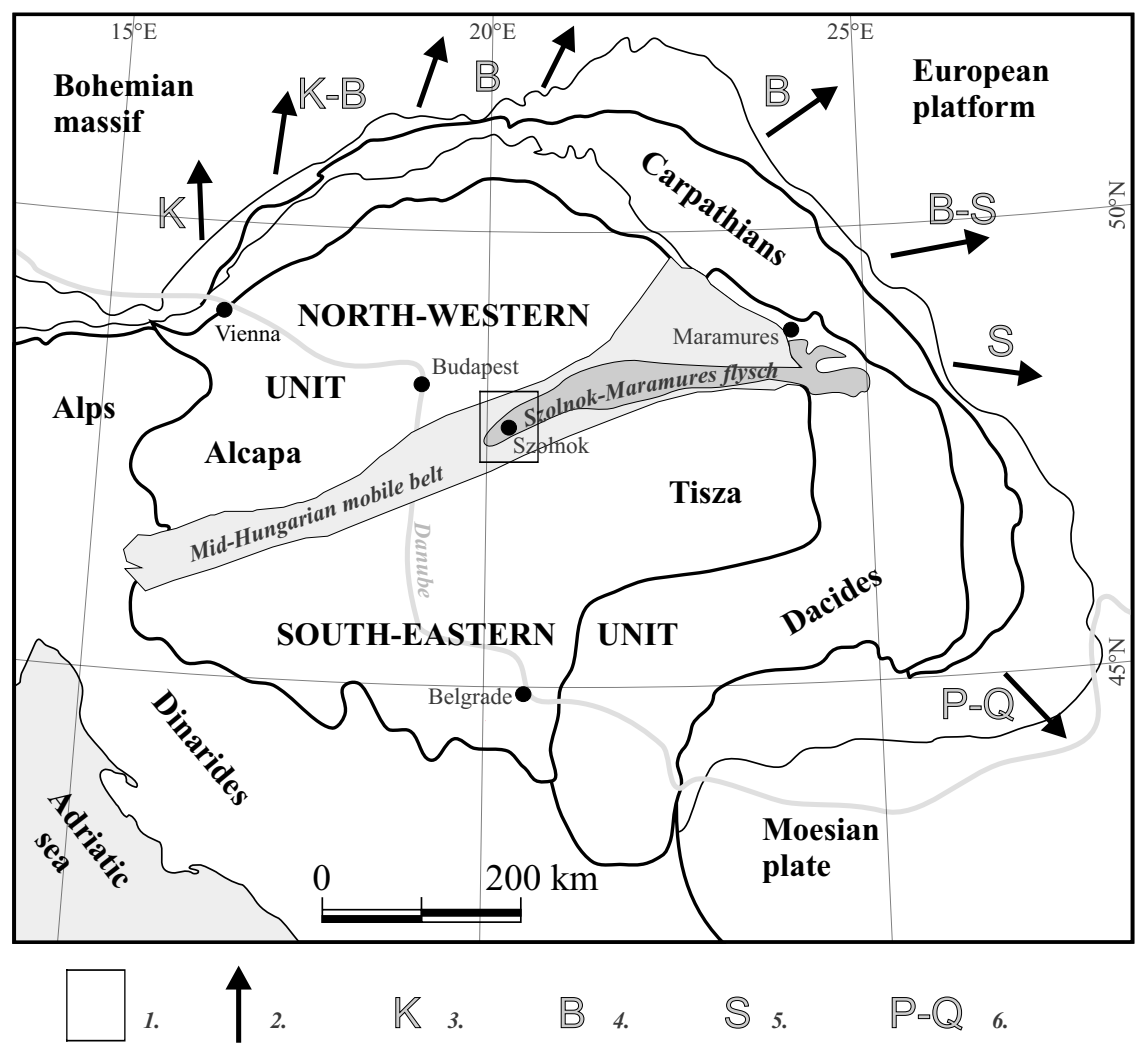

Fig. 1. Sketch of the Carpathian/Pannonian area (after Balla 1990 and Csontos et al., 1991) with the orogenic vectors (Jiricek, 1979) representing the displacement direction of the flysch nappes and the temporaly changing termination of the nappe transport along the Carpathian arc; Keys: 1 = Study area; $2=$ Transport direction of flysch nappes; $3=$ Karpatian (17 to $16 \mathrm{Ma}) ; 4=$ Badenian $(16$ to $14 \mathrm{Ma}) ; 5=$ Sarmatian (14 to $12 \mathrm{Ma}) ; 6$ = Pliocene-Quaternary (6 to $0 \mathrm{Ma}$ )

the Mid-Hungarian mobile belt. We show in this paper that relative motion between these two terranes has continued up to recent time.

In the study area two basins of different age and areal extent overlie the Mesozoic rocks of the Mid-Hungarian mobile belt: the Szolnok flysch trough and the Pannonian basin. The flysch is named after the city Szolnok situated in the central part of the Great Hungarian Plain. It is important to note that the flysch trough continues in Romania, where it crops out in the Maramures area (Fig. 1). The flysch trough was filled up during the Late Cretaceous through Paleogene, and the development of the Pannonian basin started in the Middle Miocene. Thus the Szolnok flysch basin predated, while the Pannonian basin postdated the major block movements and deformations associated with the juxtaposition of the Alcapa and Tisza terranes. This implies that the Paleogene basin was affected by the Late Oligocene - Early Miocene transpressional deformations, while the Pannonian basin saw an extensional collapse of the flysch trough and the subsequent reactivations of these structures throughout the basin evolution.

The tectonic activity between the two terranes has been studied also by geological fieldwork (Györfi et al., 1999, and Fodor et al., 1999). They observe that compressional events occured during Early Miocene with $\sigma 1$ oriented towards the
NNW, which overthrust the flysch rocks on the top of the Tisza-Dacia terrane. This deformational phase could have induced large block rotations in both units as suggested by Fodor et al. (1999) in their new synthesis of paleostress data related to the Tertiary tectonic evolution of the Pannonian basin system.

The contemporaneous tectonic stress and crustal deformation in and around the Pannonian basin was studied by Gerner et al. (1999), with the use of stress determinations and finite element modelling. Their results show that the alignment of the largest horizontal stress exhibits a radial (fanlike) pattern in the Pannonian-Carpathian region. The radial stress pattern can be explained by the crustal deformation of the area (Bada et al., 1998; Bada and Horváth, 1998), which is controlled by counterclockwise rotation of Adria with respect to Europe around a pole at $45^{\circ} \mathrm{N}$ latitude and $6-10^{\circ} \mathrm{E}$ longitude inferred from satellite geodesy and earthquake slip vectors.

\subsection{Formation of the flysch trough}

The Szolnok flysch trough in Hungary is present only in the subsurface, beneath the Neogene Pannonian basin (BáldiBeke et al., 1981), however, in Romania it crops out in the Transcarpathian (Maramures) Flysch zone of the inner East 


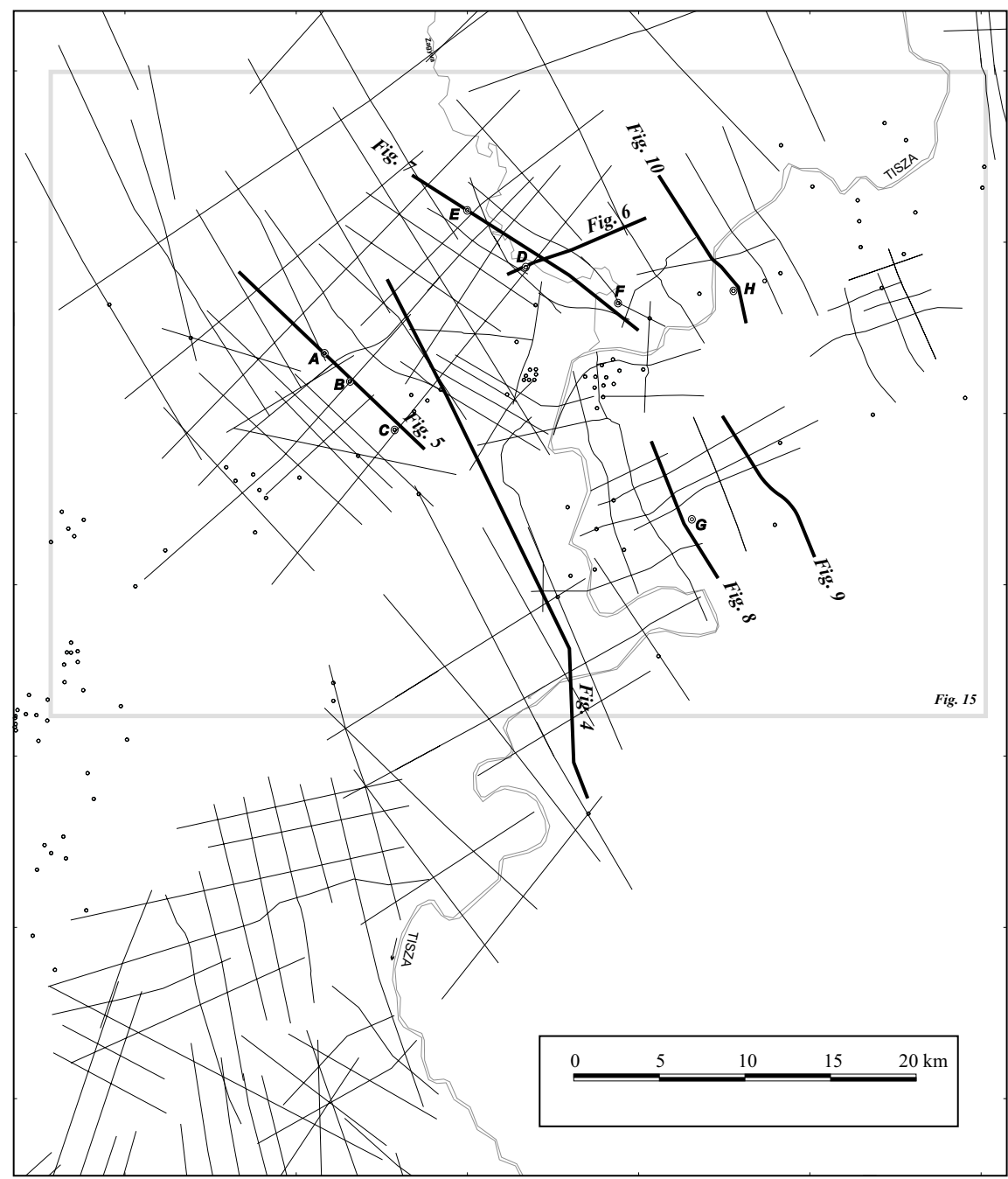

1 .

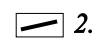

3.

$\oplus^{\oplus A} 4$.

Fig. 2. Basemap of all the seismic lines and boreholes used for interpretation; Keys: $1=$ Interpreted seismic line; $2=$ Seismic section shown in this paper; 3 = Interpreted drill hole; 4 = Drill holes shown on the seismic sections in this paper

Carpathians (Sandulescu et al., 1981; Kilényi et al., 1991). Based on micropaleontological investigations on core samples, the formation of the flysch deposits occured in a deepwater basin. A gradual change from the deep-water conditions to shallower environments proceeded until the end of the Oligocene. The Szolnok flysch is characterised by a non-continuous biostratigraphic record: Late Campanian Early Maastrichtian; Late Palaeocene - Early Eocene; Middle Eocene - Late Eocene and Late Oligocene nannoplankton zones were detected in the stratigraphic record (BáldiBeke et al., 1981; Báldi-Beke and Nagymarosy, 1992). The amount of erosion of the flysch rocks was significant and very variable: no post-Eocene rocks occur in the southwestern segment, while in the Northeast even Early Miocene flysch rocks have been found (Nagymarosy and Báldi-Beke, 1993).

Although more than 100 hydrocarbon exploration wells have reached the Szolnok flysch, its total thickness and litho- logical composition is not known fully, because boreholes drilled through the entire complex at the flanks. In more axial positions several wells penetrated more than $1000 \mathrm{~m}$ of coarse and fine turbiditic clastics of the Szolnok flysch, where the maximum thickness of the flysch can be estimated 2.0-2.5 km on the basis of deep seismic profiles (D.Lôrincz, 1996a, b).

Kôrössy $(1959,1977)$ and Szepesházy (1973) using well logs and core samples, demonstrated the strong deformation of the Szolnok flysch sequence. Former seismic studies (Horváth, 1987; Pogácsás et al., 1989; Kilényi et al., 1991; D.Lőrincz and Szabó, 1993) suggested that compressional strike-slip movements were the dominant form of tectonic activity in the exploration area. The Pannon Geotraverse, which is a deep seismic profile about $30 \mathrm{~km}$ to the East of the study area, indicates a wide transcurrent zone in the upper and possibly even in the lower parts of the Earth's crust (Posgay et al., 1990; Posgay and Szentgyörgyi, 1990). 


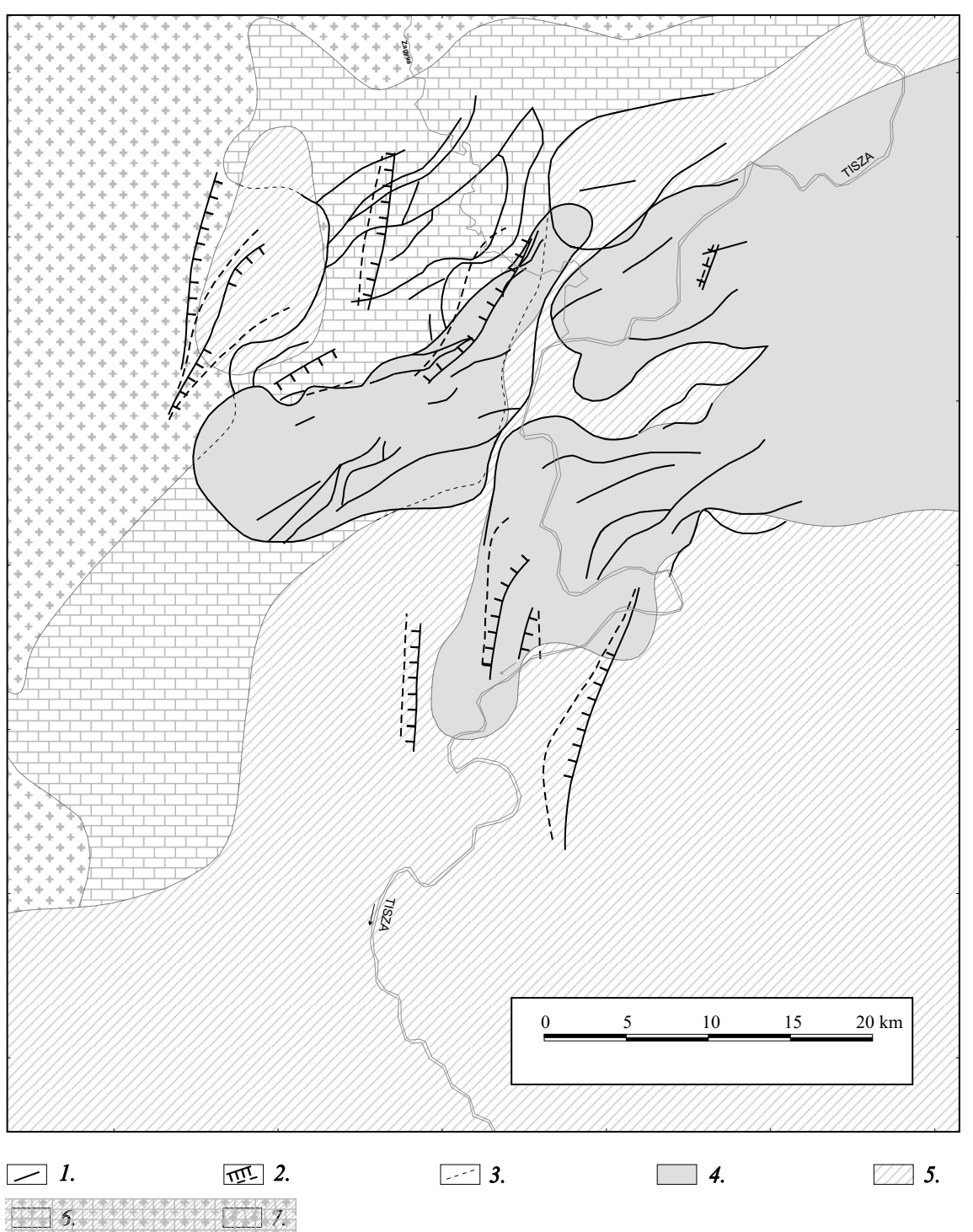

Fig. 3a. Study area, structural sketch of the base Neogene (displaying prerift and synrift tectonic phases); Keys: $1=$ Early Miocene convergent wrenching; 2 = Middle Miocene extension; 3 = Covered boundary of basement rocks; 4 = Upper Cretaceous - Paleogene flysch; $5=$ Lower Cretaceous volcaniclastic sediments; $6=$ Mesozoic clastics and carbonates; 7 = Precambrian crystalline schists.

This strike-slip zone appears to be a regional feature as it is known in the western continuation of the study area between Szolnok (at the Tisza) and Paks (at the Danube) where the flysch rocks are not present (Fig. 1). The nature and Pliocene-Quaternary reactivation of this fault has been demonstrated by reflection seismic sections (Pogácsás et al., 1989; Horváth et al., 1993) and high resolution onland and river seismic surveys (Gúthy and Hegedús, 1988; Tóth and Horváth, 1997). The neotectonic importance of this zone is shown by the occurrence of a large historical earthquake in Kecskemét at 1911 ( $8^{\circ}$ epicentral intensity on MSK-64 scale; Bisztricsány, 1977).

\section{Tectonic evolution as inferred from seismic interpre- tation}

A detailed structural analysis has been carried out in the $100 \times 60 \mathrm{~km}^{2}$ exploration area, which is located in the western part of the Szolnok flysch (Fig. 1). Studies based on the integrated interpretation of $1700 \mathrm{~km}$ of migrated seismic time sections and lithological data from about 150 hydrocarbon exploration boreholes. The basemap of seismic lines and boreholes are displayed in Fig. 2. The tectonic analysis of the sediments was supported by sequence stratigraphic interpretation of seismic and 42 well-log data. Well-log inserted on the seismic profile is shown in Fig. 7.

The sedimentary rocks known from the boreholes were identified on the seismic profiles on the basis of reflection patterns (amplitude, frequency, interval velocity, continua- 


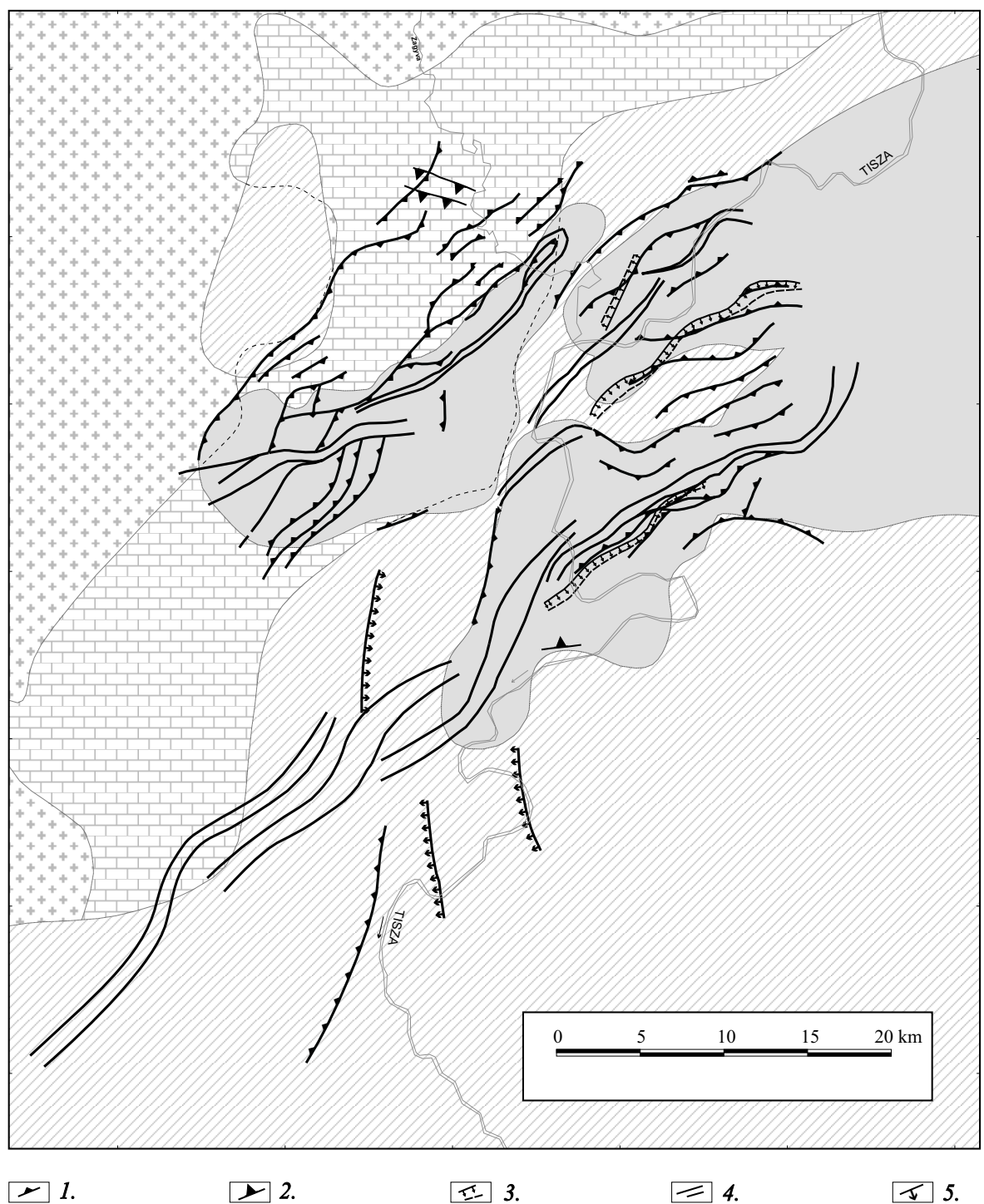

Fig. 3b. Structural sketch of the base Neogene (displaying postrift tectonic phases); Keys: $1=$ Late Miocene transpression; $2=$ Late Miocene compression; 3 = Pliocene extension; 4 = Quaternary strike-slip; 5 = Quaternary extension; the legend of lithology is the same as in Fig. 3a.

tion and arrangement of the reflections etc.) (Ádám, 1987). In this way the strastigraphic information of the boreholes has been extended by the seismic profiles. Seismic reflection pattern of the different stratigraphic features in the exploration area are shown on the Table 1 . The seismic characters are presumably influenced by the complicated fault systems causing difficult decisions during the interpretation.

One of the most important purposes of detailed structural analysis was to determine the possible $\mathrm{HC}$ migration pathes and trapes for hydrocarbon exploration. Besides, the particular knowledge of neotectonic events can be very useful for planning of new industrial plants in the area, because of the earthquake risk can be originated from the neotectonic activity.

In the Szolnok area the rocks below the Neogene basin fill consist of (Figs. 3a, b):
- Precambrian crystalline schists,

- Mesozoic clastics and carbonates,

- Lower Cretaceous volcaniclastic sediments,

- Upper Cretaceous-Paleogene flysch.

Seven tectonic phases can be distinguished in the seismic profiles, which are illustrated by seven characteristic sections and their interpretation (Fig. 4 to Fig. 10). Location of these seismic lines is shown in Figs. 2 and 3a,b.

The identified tectonic phases and their main characteristics (age, character, size and direction) are summarised in Table 2 . The phases are classified according to their ages compared to rifting of the Pannonian basin (Middle Miocene). 
Table 1. Characteristic reflection patterns of the different stratigraphic units

\begin{tabular}{|c|c|c|c|}
\hline STR & ATIGRAPHY & \multicolumn{2}{|c|}{ REFLECTION PATTERN } \\
\hline SB & $\begin{array}{l}\text { Sequence } \\
\text { boundaries of } \\
\text { Pannonian (Upper } \\
\text { Miocene, Pleistocene) } \\
\text { sediments }\end{array}$ & 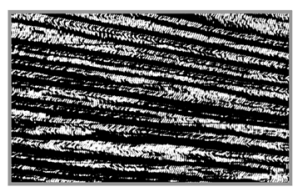 & $\begin{array}{l}\text { high amplitude, } \\
\text { good continuity }\end{array}$ \\
\hline & $\begin{array}{l}\text { Miocene } \\
\text { sediments }\end{array}$ & 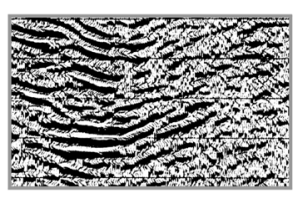 & $\begin{array}{l}\text { medium amplitude and } \\
\text { continuity }\end{array}$ \\
\hline $\begin{array}{l}\nabla \nabla \nabla \nabla \nabla \\
\nabla \nabla \nabla \nabla \nabla \nabla \\
\nabla \nabla \nabla \nabla \nabla \\
\end{array}$ & $\begin{array}{l}\text { Miocene } \\
\text { volcanics }\end{array}$ & 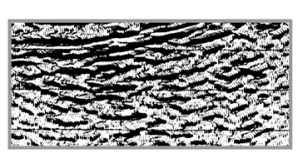 & $\begin{array}{l}\text { medium amplitude, } \\
\text { chaotic }\end{array}$ \\
\hline & $\begin{array}{l}\text { Upper Cretaceous- } \\
\text { Paleogene flysch }\end{array}$ & 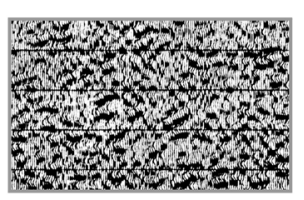 & reflection free \\
\hline F/ & $\begin{array}{l}\text { Lower Cretaceous } \\
\text { volcaniclastic } \\
\text { sediments }\end{array}$ & 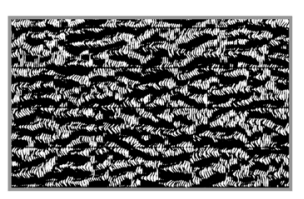 & $\begin{array}{l}\text { high amplitude, } \\
\text { poor continuity }\end{array}$ \\
\hline لـ & $\begin{array}{l}\text { Mesozoic clastics } \\
\text { and carbonates }\end{array}$ & & $\begin{array}{l}\text { changeable amplitude, } \\
\text { medium continuity }\end{array}$ \\
\hline++++ & $\begin{array}{l}\text { Precambrian } \\
\text { crystalline schists }\end{array}$ & ans & $\begin{array}{l}\text { low amplitude, } \\
\text { chaotic }\end{array}$ \\
\hline
\end{tabular}

\subsection{Prerift tectonism}

Mesozoic overthrusting (phase I.)

The tectonic evolution of the area during the Mesozoic was influenced by the opening and closure of the Tethys, and the location of the terranes at the different margins of the Tethys ocean (Fülöp, 1989). The most significant tectonic deformation took place during the Late Cretaceous, when convergence of the continental margins and subduction of the Tethys ocean occured. During this period, three subperiods of compressional events can be recognized: the Austrian phase (Aptian-Albian), the Pre-Gosau phase (Cenomanian-
Turonian) and the Laramian phase (Maastrichtian-Danian) (Horváth and Tari, 1999).

In the seismic profiles of the Szolnok area the Mesozoic overthrusts can be observed in the Mesozoic carbonates and clastic sedimentary rocks, and oldercrystalline schists. On the basis of studies made by Rumpler and Horváth (1988) and Tari (1996) it is known that the Late Cretaceous overthrusting has produced a nappe transpore of several $100 \mathrm{~km}$, and generally NW vergence in the whole Pannonian area. The Mesozoic tectonism appears with similar characteristics in the studied area. Some interpreted detachment planes of the overthrusts can be seen in the seismic sections of Figs. 4 and 5 . 

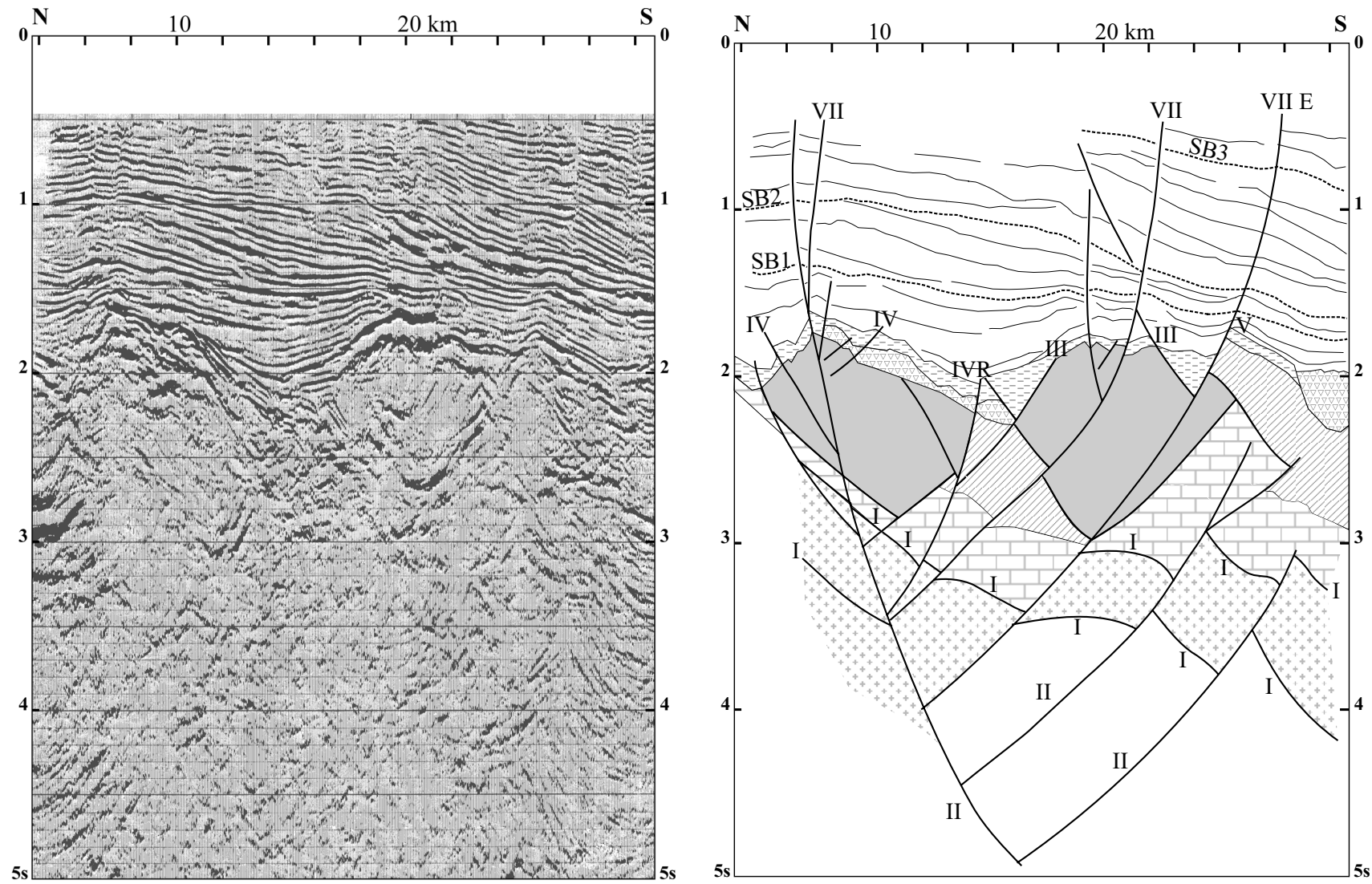

Fig. 4a. Deep seismic profile PGT-3 ((a) migrated time section imaging with vertical extension; (b) interpreted version).

Table 2. Attributes of the tectonic phases

\begin{tabular}{|r|l|l|l|l|l|}
\hline & AGE & CHARACTER & MAGNITUDE & MOVEMENT & STRIKE \\
\hline I. & Mesozoic & overthrusting & x.100 km & NW & NE-SW \\
\hline II. & Early Miocene & $\begin{array}{l}\text { convergent } \\
\text { wrenching }\end{array}$ & x.100 km & dextral & ENE-WSW \\
\hline III. & Middle Miocene & extension & $1.3 x$ & WNW, ESE & NNE-SSW \\
\hline IV. & Late Miocene & transpression & $5-10 \mathrm{~km}$ & sinistral & ENE-WSW \\
\hline V. & Late Miocene & compression & $1-5 \mathrm{~km}$ & NNE & WNW-ESE \\
\hline VI. & Pliocene & extension & $1.1 \mathrm{x}$ & NW, SE & NE-SW \\
\hline VII. & Quaternary & strike-slip & $1-5 \mathrm{~km}$ & sinistral & NE-SW \\
\hline
\end{tabular}



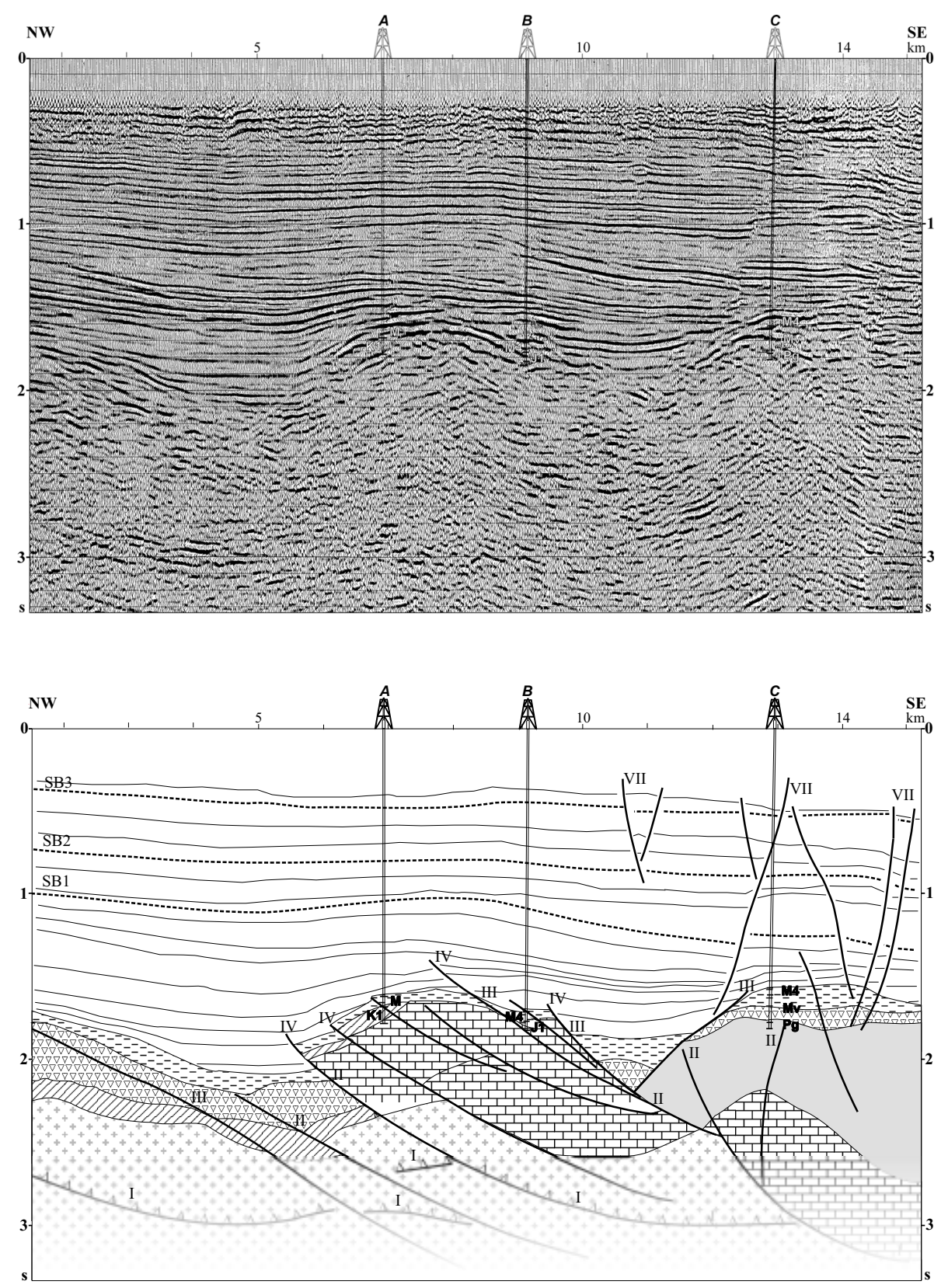

Fig. 5. Seismic time section ((a) migrated version; (b) interpreted version); Keys: $M=$ Miocen; K1 = Lower Cretaceous; $M 4=$ Miocene Badenian; J1 = Jurassic Lias; Mv = Miocene volcanics; Pg = Paleogene.

Early Miocene convergent wrenching (phase II.)

The interpretation of this phase as wrench fault tectonics is based on the following observations:

The Pannon Geotraverse (a deep seismic profile), which lies about $30 \mathrm{~km}$ to the east of the study area, suggests the presence of a transcurrent zone linked to the flysch belt (Posgay and Szentgyörgyi, 1990). In the "Structural sketch of the base Neogene" (Fig. 3a) long straight tectonic lines related to thrust faults of the II. tectonic phase can be seen, which are parallel with the edges of the flysch basin.

The fault-cuts of the tectonic phase II. form generally positive flower structures in the seismic profiles. Typical exam- ples are shown in Fig. 4. The positive character indicates that the wrench faulting was combined with compression in a NW direction. These profiles suggest that the flysch anticlines are created by the convergent wrenching.

Figure 6 shows more direct evidence of convergent wrench tectonics. Two different sequences occur side by side with different reflection image. The contact of the basement blocks is covered by compressed flysch and Miocene volcano-sedimentary rocks.

The deposition of the Szolnok flysch took place during the Upper Cretaceous - Early Miocene (Nagymarosy and BáldiBeke, 1993), along the right-lateral transcurrent fault of the 

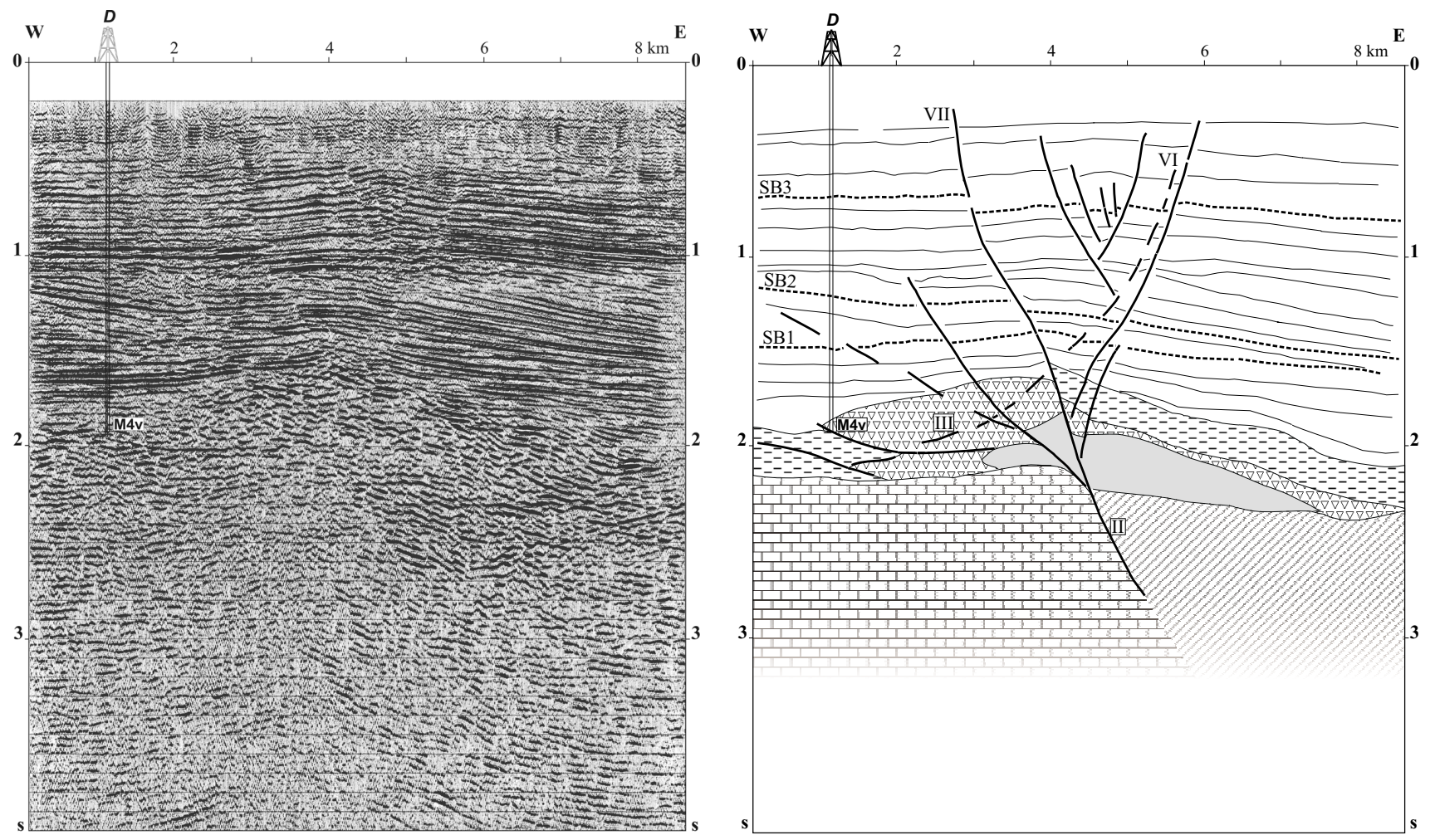

Fig. 6. Seismic time section ((a) migrated version; (b) interpreted version); Key: M4v= Miocene Badenian volcanics.

Alcapa and Tisza-Dacia terranes (Csontos et al., 1992). It is our phase II. tectonics.

In summary Early Miocene wrenching was combined with compression in a NW-SE direction. It has a right-lateral (dextral) movement-direction, and an ENE-WSW strikedirection. Its displacement can be estimated to be a few $100 \mathrm{~km}$.

\subsection{Synrift tectonism}

\section{Middle Miocene extension (phase III.)}

Middle Miocene extension is represented by low angle normal faults and listric faults on the seismic sections. The amount of extension can be estimated to be about a factor of 1.3 on the basis of seismic images (Figs. 4, 5 and 7).

The Szolnok flysch is not a continuous feature, as it was supposed on the basis of geological data (Fülöp et al., 1987), but is cut into fragments by tectonic movements and erosion.

\subsection{Postrift tectonism}

\section{Late Miocene transpression (phase IV.)}

The Late Miocene transpression reactivized the Early Miocene wrench fault system on a smaller scale and in opposite sense.

Seismic examples of this phase can be seen in the Figs. 4, 5, 7, 8, 9 and 10. The Figs. 9 and 10 provide an ex- cellent seismic example of the Late Miocene transpression. The reactivation is proved by the continuity of the fault from the Lower Miocene into the Upper Miocene. These profiles and the structural sketch (Fig. 3b) demonstrate that the flysch has been thrust not only on the pre-Neogene basement, but also over the Miocene (Lower Pannonian) sediments along the northern and southern edges of the flysch belt. This phenomenon can also be found in the western boundary of the flysch, as it can be observed in the Figs. $3 b$ and 4.

The assumption concerning the sinistral sense of displacement is suggested by the location of flysch segments in relation to each other (Figs. 3a,b). The flysch flanks seem to have moved along a central, NNE-SSW directed rightlateral strike-slip fault. This fault - which is marked "IVR" on Fig. 4 - could be a dextral fault, antithetic to the main sinistral strike-slip zone. The horizontal displacement along this fault is about $5 \mathrm{~km}$, so the size of the main strike-slip fault can be thought to be $10 \mathrm{~km}$ order of magnitude.

In summary, the movement-direction of the Late Miocene strike-slip is left-lateral, and it is combined with compression in N-S direction. The displacement can be estimated at $10 \mathrm{~km}$ order of magnitude.

Late Miocene compression (phase V.)

The phase V. is characterized by thrust-folds directed from S$\mathrm{SW}$ to N-NE. The direction of compressional displacement could be N-NE as it is shown on Fig. 3b. A typical example 

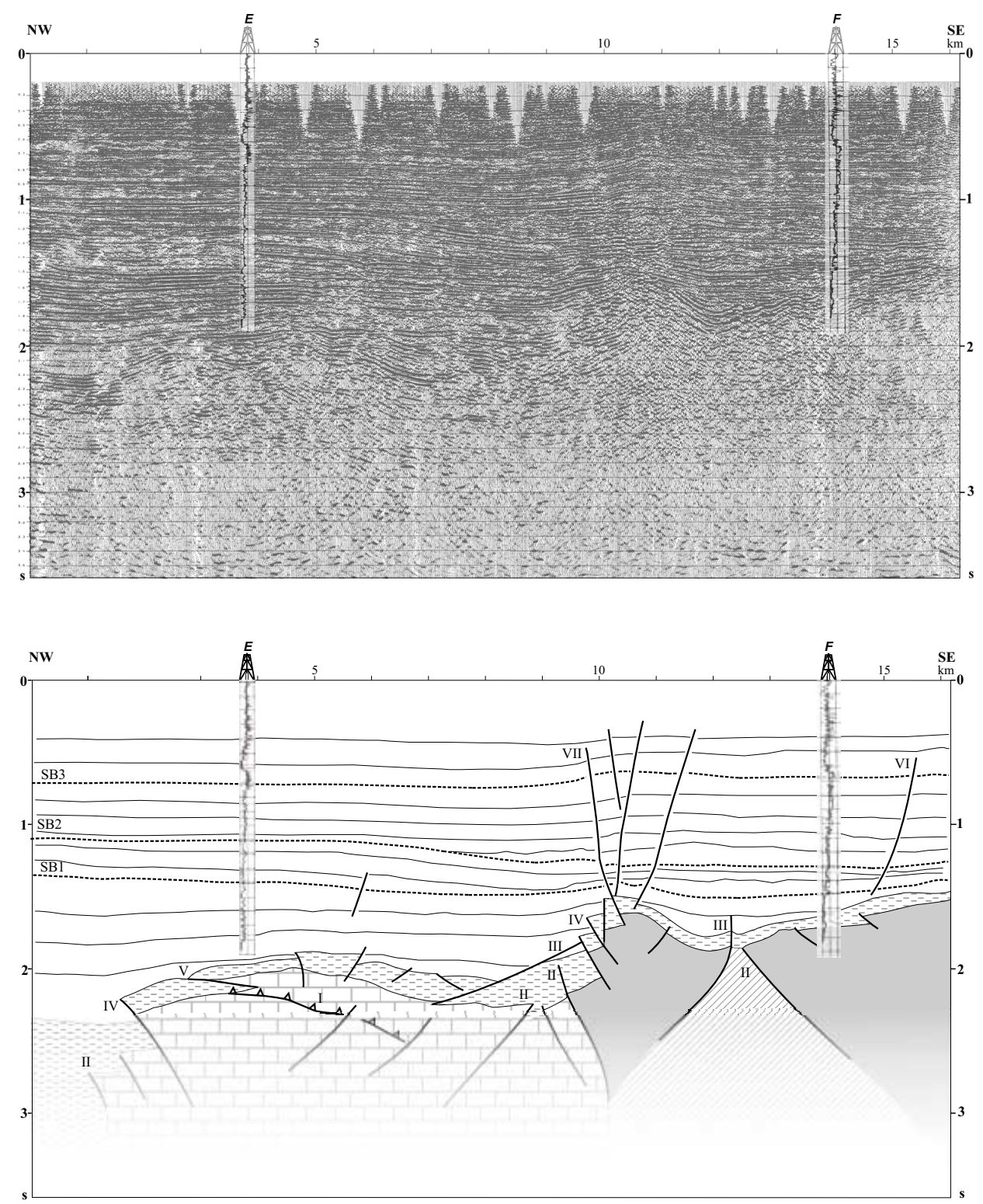

Fig. 7. Seismic time section ((a) migrated version; (b) interpreted version).

can be seen in the southern part of seismic profile of Fig. 4, where the Lower Cretaceous volcaniclastics are thrust onto the flysch, presumably due to Late Miocene compression. The interpretation is made more difficult by the presence of a neotectonic fault (VIIE phase). Another example is shown in the NW part of seismic section of Fig. 7. The size of movement can be estimated to be $1-5 \mathrm{~km}$. The presence of this tectonic phase is supported by the results of the seismic exploration in the neighbouring Paks area, where characteristic inversion structures were proved in the Upper Miocene sediments by Horváth et al. (1993, 1995).
Pliocene extension and its relation to the neotectonics (phase VI.)

The Pliocene extension is represented by synsedimentary growth faults. Examples of this phase can be observed in the southern parts of the Figs. 7 and 10, in the central part of the Figs. 6, 8 and in the northern part of Fig. 9. In the "Structural sketch of the base Neogene" (Fig. 3b) and in the "Time contour map of the SB2 sequence boundary" (Fig. 12), three zones of Pliocene extension are indicated. All of them are interpreted to be linked to the edge of the flysch welt, and the faults dip towards the deeper of the basement. This suggests that the formation of the Pliocene extensional faults was affected by the process of breaking off, which was caused by 

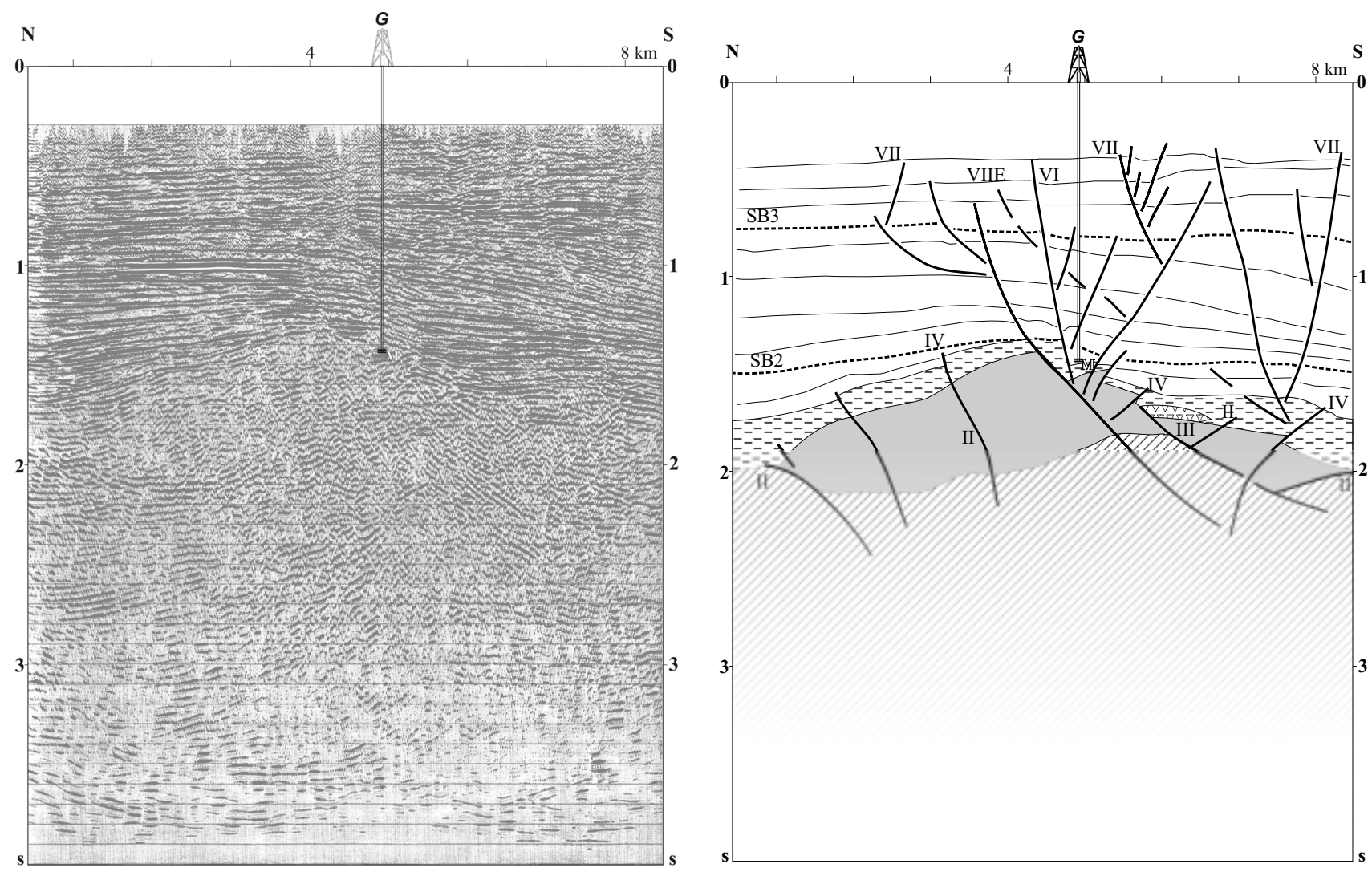

Fig. 8. Seismic time section ((a) migrated version; (b) interpreted version); Key: $M=$ Miocene.

significant vertical difference in the basement depth. This process is interpreted to have been continuously active during the Late Miocene (Pannonian) and Pliocene sedimentation.

In the zone of Pliocene extension situated on the southern edge of the flysch belt, the identification of the faults have been made more difficult by the appearance of flower structures of neotectonic phase in the same place. The strike-slip faults often cut the Pliocene extensional faults, therefore the interpretation of growth faults are very tentative. The most characteristic examples of the two tectonic phases occurred in the same place can be seen in the Figs. 8 and 9, but there are similar situation in the Fig. 6, too. The distinction of these two subsequent phases (VI. and VII.) are very complicated as it is demonstrated by the seismic profiles and the maps (Figs. 3b and 12), since the flower structures of the Quaternary strike-slip movement have overprinted the Pliocene extensional faults. The Pliocene extension was probably inverted as it is represented by the profile on Fig. 10.

The measure of Pliocene extension is about a factor of 1.1 times and the movement-direction is SE.

Quaternary strike-slip movements (phase VII.)

Three strike-slip zones were mapped (Figs. 3b and Fig. 12), which can be considered as the recent reactivation of the wrench tectonics in the area. The image of the deep seismic profile (Fig. 4) supports the assumption, that some faults of the wrench system - which had occurred in the phase II. - reoccured during the Quaternary strike-slip movements leading to characteristic flower structures in the Neogene sedimentary rocks. It means that the phase VII. is not independent: it belongs to the same earlier wrench fault system. Two Quaternary strike-slip zones are crossed by the profile of Fig. 4 . These are signed with VII, and the VIIE marks the normal faults linked to the strike-slip zones.

Three seismic sequence boundaries (SB1, SB2 and SB3) were interpreted in the Upper Miocene-Pliocene sediments for better identification of the youngest tectonics. Figure 12 presents the time contour map of the SB2. All the tectonic elements crossing SB2 are demonstrated on the map.

These are the following:

- Pliocene extension (demonstrated in all the seismic profiles of Figs. 6 to 10),

- Quaternary strike-slip zones (displayed in all the seismic profiles of Figs. 4 to 10),

- Quaternary extension elements linked to the strike-slips (shown in Figs. 4 and 8).

Determination of movement-direction was supported by the following figures.

Figure 13 (modified after Tchalenko, 1970) demonstrates the result of physical modelling of a left-lateral strike-slip published by Riedel (1929). The Riedel faults show a right stepping fault-setting. On the map (Fig. 12) the same right 


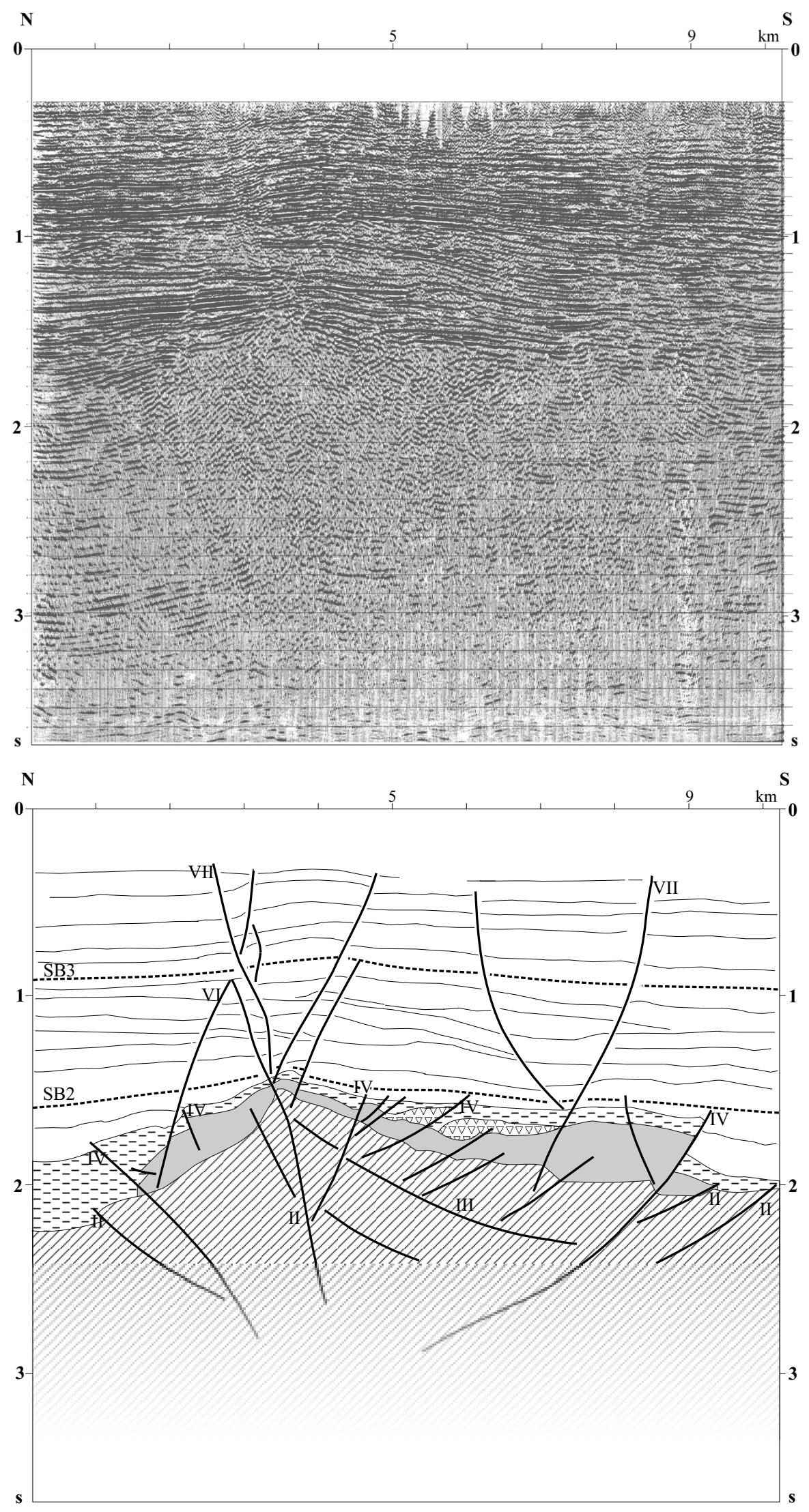

Fig. 9. Seismic time section ((a) migrated version; (b) interpreted version). 

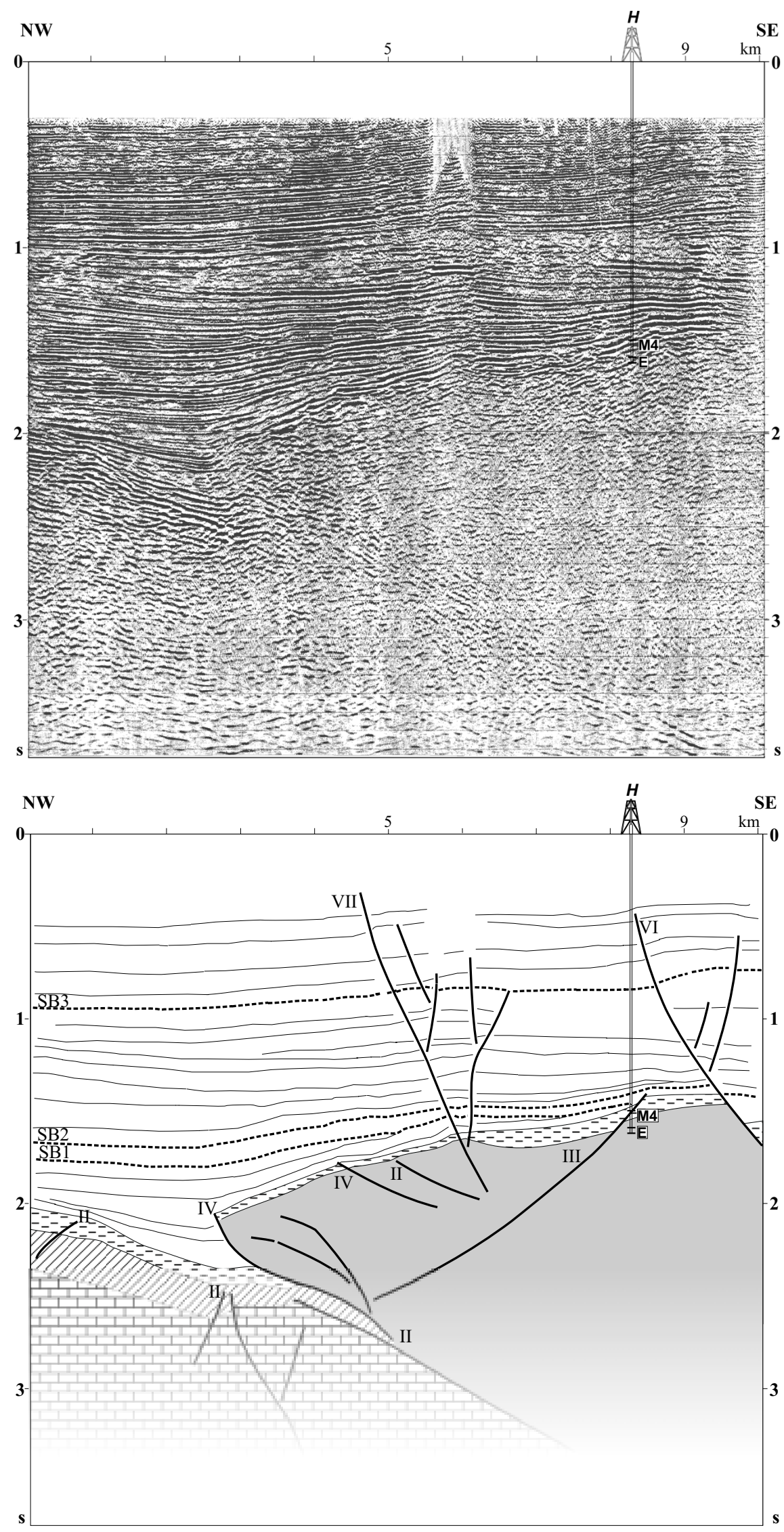

Fig. 10. Seismic time section ((a) migrated version; (b) interpreted version); Keys: M4 = Miocene Badenian; E = Eocene. 


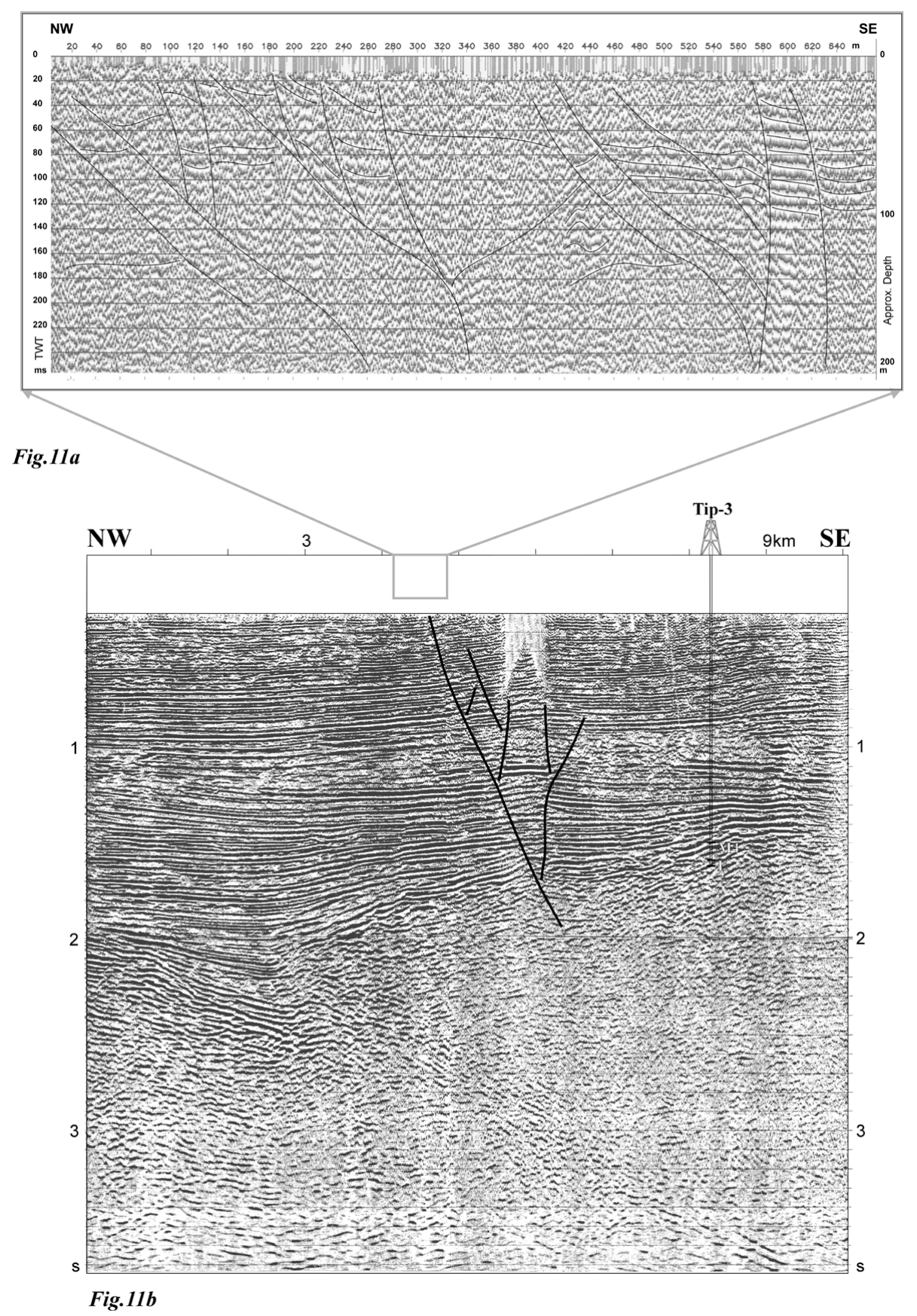

Fig. 11. Shallow seismic time section (Detzky et al., 1996).

stepping assemblage of the Riedel faults occurs in the southern strike-slip zone. In consequence, this zone can be considered a left-lateral strike-slip fault. The other two zones seem to be right-lateral ones, based on their weak en-echelon character.

Figure 14 shows the strain ellipse and the tectonic setting of a left-lateral wrench fault after Harding (1974). If we compare this wrench assemblage with the Quaternary tectonic setting in the SB2 (Fig. 12) we see an analog situation: The lower left-lateral zone corresponds to the synthetic strike-slip fault in the Harding diagram, and the upper two zones cor- respond to the antithetic fault. The location of the normal faults compared to the main fault is similar to that in the Harding picture. This comparison emphasizes that the three Quaternary strike-slip zones formed an integrated system, as it is demonstrated in the deep seismic profile (Fig. 4). This profile shows the multiphase rejuvenation of some faults of Early Miocene flower structure.

The horizontal displacements of the strike-slip movements can roughly be estimated at $1-5 \mathrm{~km}$ on the basis of time contour maps. The largest offset $(5 \mathrm{~km})$ occurred in the sinistral zone presented in the southern part of the area. It could be 

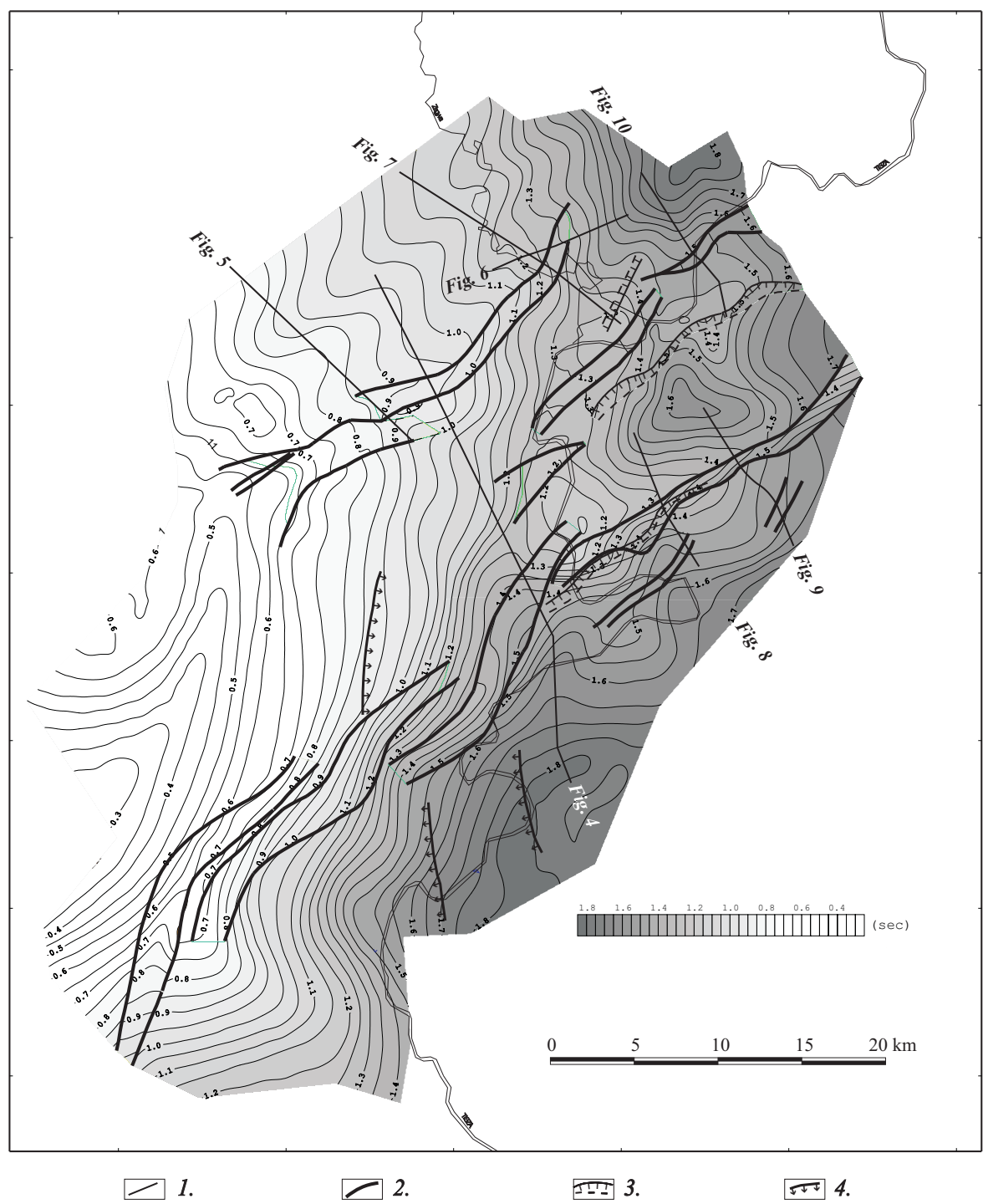

Fig. 12. Time contour map of the SB2 sequence boundary (D. Lórincz, 1996a); Keys: $1=$ line of presented seismic profiles; $2=$ Quaternary strike-slip; 3 = Pliocene extension; 4 = Quaternary extension.

the synthetic zone of the Quaternary tectonics. The horizontal displacement of the antithetic dextral zones is presumably smaller (they are about $1-2 \mathrm{~km}$ ).

The whole system of the strike-slips probably exhibits a left-lateral character, in which the three zones represent the synthetic Riedel fault and conjugate antithetic Riedel faults of the system.

In the upper $800 \mathrm{~ms}$ interval of the seismic profiles compressional effect can be recognized. It is known from literature, that strike-slip faults show compressional character in some places, and extensional character in other places, as a function of bending of the principal displacement zone (Sylvester, 1988). In the study area we can only see compressional manifestation, so we can conclude that the Quaternary strike-slip was combined with compression. The compressional character of the Quaternary strike-slip and the inversion of some Pliocene extensional faults (Fig. 9) represents a serious change of stress field during the Pliocene-Quaternary, when the extensional effect changed to compressional one.

In Fig. 15 the isopach map of Quaternary sediments compiled by Franyó (in D.Lőrincz, 1996a) can be seen. Taking into consideration the velocity values in the area and datum level of the profiles, the top of the fault could reach as shallow as the $300 \mathrm{~m}$ level. The thickness of Quaternary sediments, where the strike-slip faults cut them, is about $300 \mathrm{~m}$ or more on the basis of the isopach map. Therefor the age of this fault can be considered to be Quaternary.

The hydrocarbon exploration seismic sections with normal penetrating depth do not have signals in the upper $300 \mathrm{msec}$ interval, as it can be seen in all of the presented seismic profiles. The location of the shallow seismic profile (Fig. 11a) and the normal section (Fig. 11b) is demonstrated on the "Quaternary isopach map" (Fig. 15), where Fig. 10 is the same as the Fig. 11b. It was a question whether the faults 


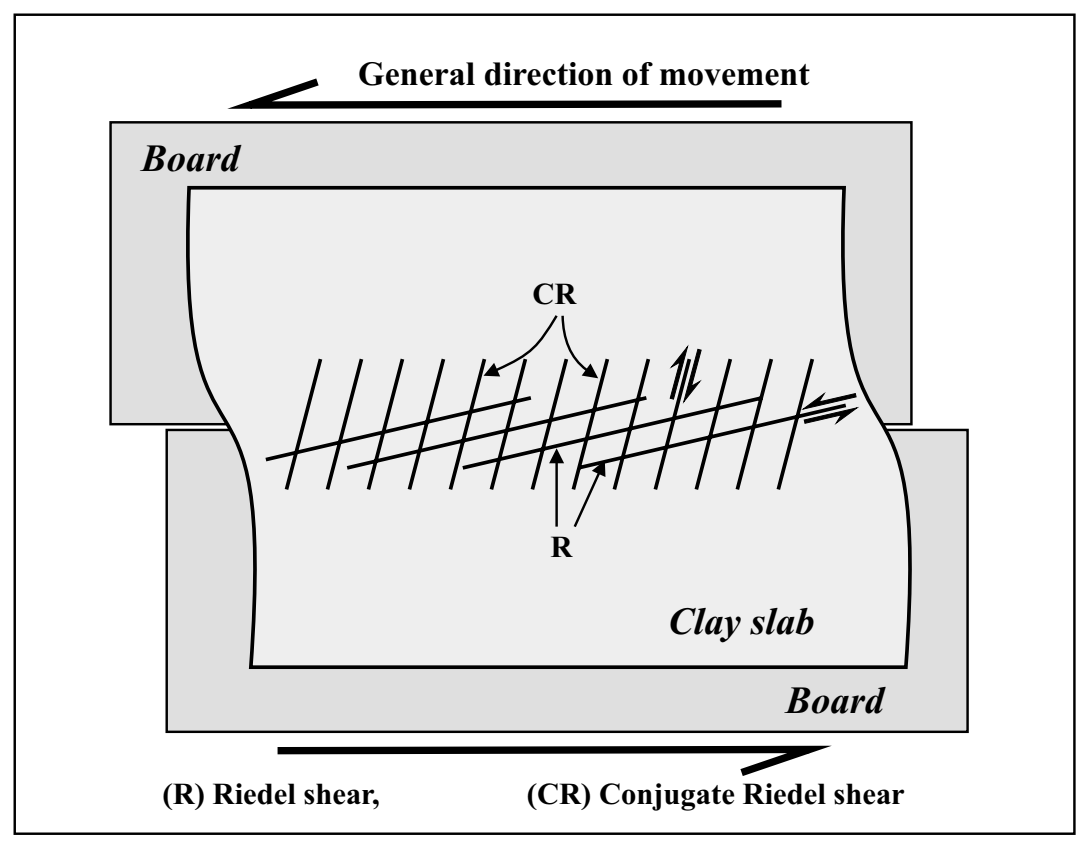

Fig. 13. Diagram of the Riedel experiment (Riedel, 1929) of the left-lateral strike-slip movement (after Tchalenko, 1970).

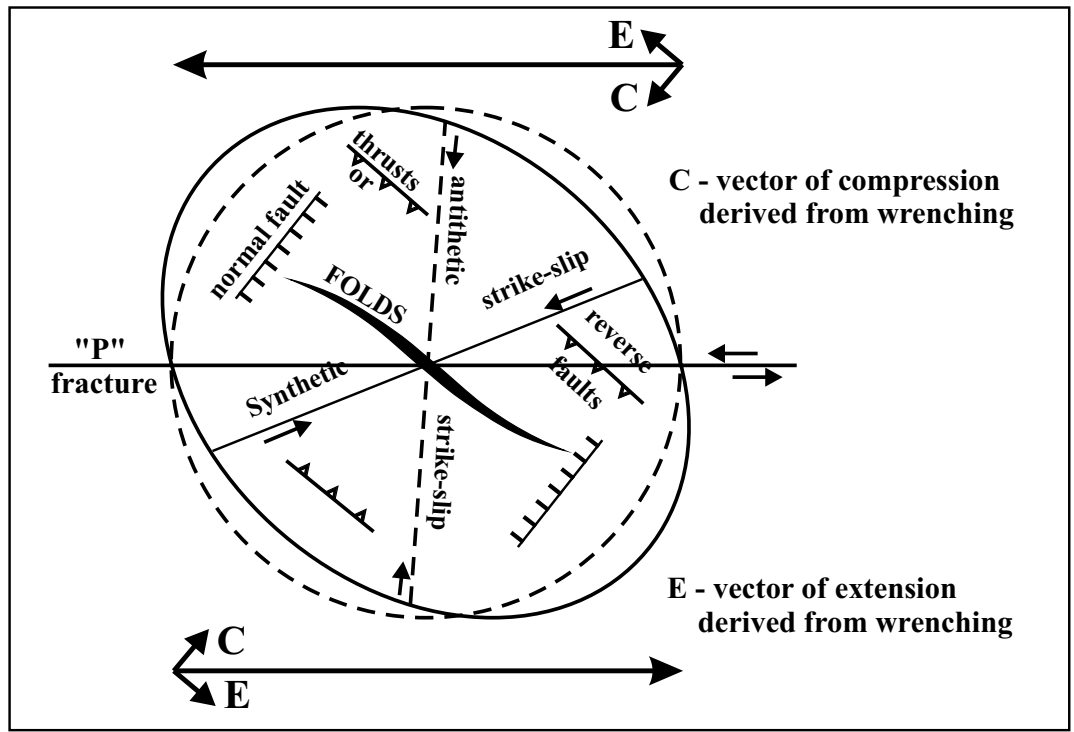

Fig. 14. Wrench assemblage from a left-lateral couple (Harding, 1974).

identified in the normal seismic profiles could be present in the muted shallowest parts of the seismic sections. Shallow seismic measurements were carried out over the frozen backwaters of the river Tisza which crossed faults of strike-slip zones. The reflection image on the shallow seismic profile (Fig. 11a) is cut into two segments by a fault. The lower left side is characterized by strong, parallel reflections and the upper right side shows a chaotic reflection image. The geometry of the shallow profile compared to the normal section provides a more flattened position of the fault. The fault appears to terminate as a depth of $20 \mathrm{~m}$ as can be seen in the shallow profile. Tóth and Horváth (1997) also suggested active faulting in the immediate western extension of the Szolnok flysch belt.

\section{Stress field history}

On the basis of character, size and direction of the tectonic phases the stress field history of the arc can be depicted. The main features of the identified tectonic phases are summarized in Table 2 and Table 3, where the most characteristic structural elements of the tectonic phases are illiustrated. 


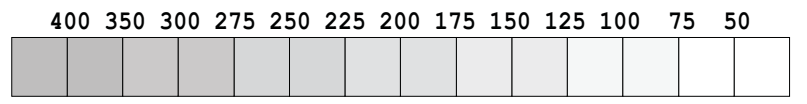

$(\mathrm{m})$

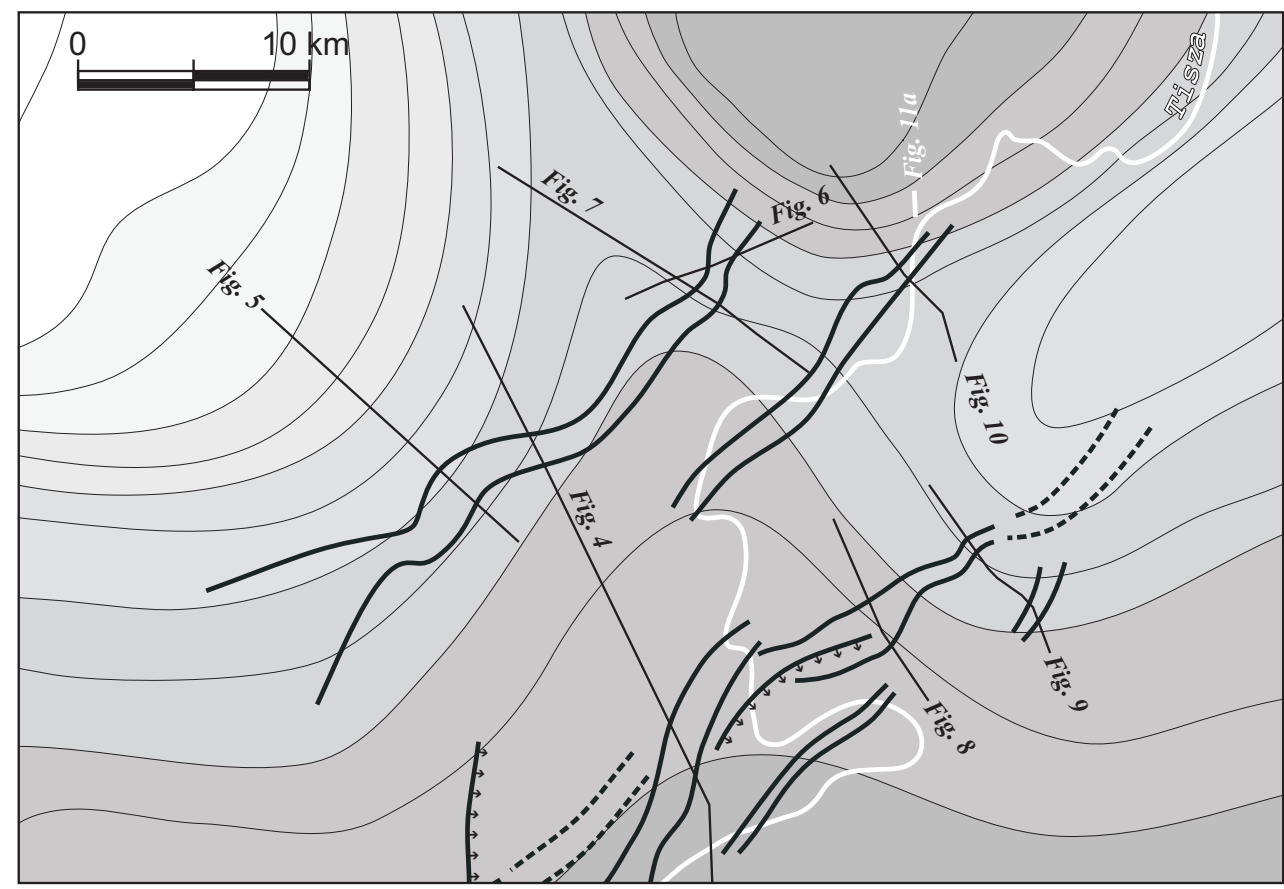

$\square$ 1. $\quad 2 . \square 3 . \square 4$

Fig. 15. Quaternary isopach map (Franyó, 1994, in D.Lőrincz, 1996a); Keys: 1 = line of presented seismic profile; 2 = Quaternary strike-slip; $3=$ Quaternary extension; 4 = line of shallow seismic profile shown in Fig. 11a.

Table 3. Stress field history

I. Mesozoic overthrusting

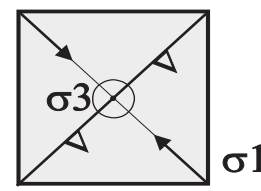

IV. Late Miocene transpression

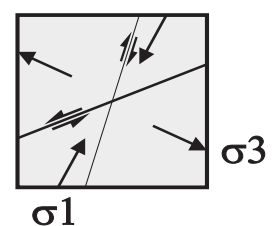

II. Early Miocene convergent wrenching

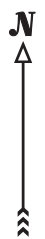
V. Late Miocene compression

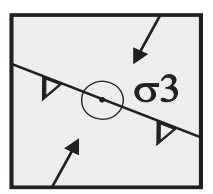

$\sigma 1$

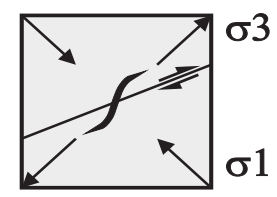

VI. Pliocene extension

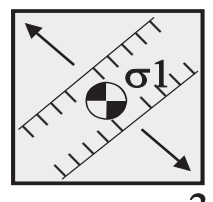

III. Middle Miocene extension

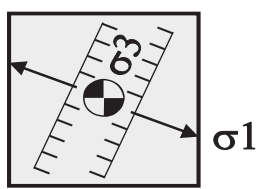

VII. Quaternary strike slips

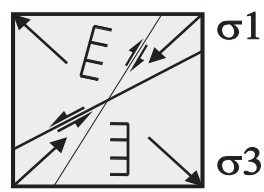

sigma1: maximum principal stress sigma3: minimum principal stress 
Identification of the stress fields was supported by known relationships between the principal stresses and basic types of resultant faults: normal-, reverse- and strike-slip (Anderson, 1951). In practice clear types of faults rarely occur, they are often combined with each other, as is demonstrated by this study.

The stress field history shows a systematic horizontal rotation of the largest horizontal stresses ( $\sigma 1$ or $\sigma 2)$ from NW to NE (Table 3). Figure 1 demonstrates that the subduction related nappe displacement in the Outer Carpathian underwent similar clockwise rotation during the Neogene. The cause of nappe displacement was the collision of the CarpathianPannonian area with the European foreland when all the subductible lithosphere was consumed. It is suggested that the horizontal rotation of largest horizontal stress in the Pannonian region is a consequence of this progressive West to East migration of onset of continental collision along the Carpathian arc.

\section{Conclusions}

The area shows characteristic phenomena of multiple tectonic events and fault reactivation. Typical flower structures, long straight fault zones in the basement coupled with other criteria of wrench faults summarised by Harding (1990), indicate the presence of strike-slip zones. The latest activity should be Quaternary.

Some faults of these system were active in the Late Miocene with smaller scale $(5-10 \mathrm{~km})$ horizontal displacement and opposite direction (sinistral sense), confirming the effect of an Early Miocene tectonic phase, and showing similarly compressional character. These zones are associated with a wrench system with convergent dextral character formed in the Early Miocene. Early Miocene wrench faulting can be characterized by a few $100 \mathrm{~km}$ horizontal displacement.

Besides the multiphase wrench system compressional and extensional faults are also characteristics in the area. Large scale thrust faulting occurred during the Cretaceous, and a smaller Late Miocene compressional event can be identified, too. The main extensional movement took place in the Middle Miocene, but there was a smaller extension during the Pliocene.

Some phases represent the rejuvenation of earlier activities (generally in smaller scale and opposite direction) while others are independent from the older movements. By analyzing the stress field history of the study area (Table 3) we conclude, that the horizontal rotation of the largest horizontal stresses has been controlled by the termination of subduction along the Carpathian arc. Complete consumption of subductible lithosphere and, hence, onset of continental collision, exhibit a progressive shift along the arc from the Western towards the Eastern Carpathians, and it is reflected by the stress field history in the more internal Szolnok flysch belt.
It is important to highlight, that the seismic interpretation is limited by the structural complexity of the study area, which has had an impact on the seismic reflection pattern.

Acknowledgements. This work represents part of the results of $\mathrm{PhD}$ thesis work made by one of the authors (Katalin D.Lórincz) at the Eötvös Loránd Geophysical Institute of Hungary (D.Lőrincz, 1997). She gratefully thanks Prof. Frank Horváth from the Geophysical Department, Eötvös University for the supervision of this PhD thesis. The authors greatly appreciate the accurate and helpful work of all participants of this investigation in the Eötvös Loránd Geophysical Institute of Hungary, (ELGI, H-1440 Budapest, POB 35). The most important professional help was provided by Dr. Éva Kilényi and Dr. Károly Posgay. They are indebted to director of ELGI, Dr. Tamás Bodoky for the aiding of this work.

The authors are grateful to the MOL Hungarian Oil and Gas Co., the Hungarian Geological Survey, and the Mining Authority for providing the lithological data of the boreholes and the well-logs, the reports of the previous measurements and for the cooperation of the individuals concerned. They thank Dr. Béla Bardócz, the former director of the Domestic Research Department of MOL, for giving permission to the seismic data for this study.

The seismic measurements were carried out by the Eötvös Loránd Geophysical Institute (ELGI) on behalf of the Hungarian Oil and Gas Trust (recently: Hungarian Oil Company: MOL Rt.). The financial support provided by the Hungarian Scientific Research Foundation (project number: T 4332) and the Hungarian Geological Survey is gratefully acknowledged.

The authors express their appreciation to Dr. G. Bada for his constructive critical discussions, and all to reviewers of this paper suggesting many improvements.

\section{References}

Ádám, O.: Seismic exploration I-II. Textbook, Budapest, 1987.

Anderson, E. M.: The dynamics of faulting and dyke formation, with applications to Britain: Edinburgh, Oliver and Boyd, 2nd ed., 206 p., 1951

Bada, G., Cloetingh, S. A. P. L., Gerner, P., and Horváth, F.: Sources of recent tectonic stress in the Pannonian region: inferences from finite element modelling. Geophys. J. Int. 134, 87-101, 1998.

Bada, G. and Horváth, F.: Recent tectonics in the Pannonian basin. The World of Nature 1998/II. Special issue, 1998.

Balla, Z.: Analysis of the anti-clockwise rotation of the Mecsek Mountains (southwest Hungary) in the Cretaceous: interpretation of paleomagnetic data in the light of the geology. Geophysical Transactions, 32, 147-181, 1986.

Balla, Z.: The Pannonian basin: a study in basin evolution: discussion. AAPG Bull 8: 1273-1280, 1990.

Báldi-Beke, M., Horváth, F., and Nagymarosy, A.: Biostratigraphic investigation on flysch formations in the Great Hungarian Plain. Annual Report of the Hungarian Geological Survey from year 1979. Budapest, 143-158, 1981.

Báldi-Beke, M. and Nagymarosy, A.: On the age of the Szolnok flysch and its possible correlation with the Carpathian flysch units. Knihovnicka ZPN, 14b, vol. 2, 37-48, 1992.

Bisztricsány, E.: The earthquake hazard in the Carpathian area. Földt. Közl. 107, 94-101, 1977. 
Csontos, L., Tari, G., Bergerat, F., and Fodor, L.: Evolution of the stress fields in the Carpatho-Pannonian area during the Neogene. Tectonophysics, 199, 73-91, 1991.

Csontos, L., Nagymarosy, A., Horváth, F., and Kovács, M.: Tertiary evolution of the Intra-Carpathian area: a model. Tectonophysics, 208, 221-241, 1992.

Detzky, G., D.Lő́rincz, K., and Markos, T.: New experiences of the shallow water seismic measurements in the Eötvös Loránt Geophysical Institute. Symposium of the Hungarian Geologists and Geophysicists, Kerekegyháza, Program, 20-21, 1996.

D.Lőrincz, K. and Szabó, P.: Seismic analysis of multiphase tectonics in the central part of the Pannonian basin in Hungary, in: Spencer, A. M. (Ed.): Generation Accumulation and Production of Europe's Hydrocarbons III., Special Publication of the European Association of Petroleum Geoscientists No. 3., SpringerVerlag, Berlin - Heidelberg, 311-323, 1993.

D.Lórincz, K.: Detailed tectonic analysis in the central part of the Great Hungarian Plain. Report for Hungarian Scientific Exploration Fundation, project No.T4332. Data store of Eötvös Loránd Geophysical Institute of Hungary, pp. 1-39, 1996a.

D.Lórincz, K.: Determination of stress-field history on the basis of multiphase tectonics identified in the seismic profiles, in the Western part of the Szolnok flysch belt. Hungarian Geophysics, 37, 4, 228-246, 1996b.

D. Lórincz, K.: Detailed tectonic analysis in the western part of the Szolnok flysch trough on the base of seismic and well data. $\mathrm{PhD}$ thesis work, Budapest, 1-122, 1997.

Fodor, L., Csontos, L., Bada, G., Györfi, I., and Benkovics, L.: Tertiary tectonic evolution of the Pannonian basin system and neighbouring orogens: a new synthesis of paleostress data, in: Durand, B., Jolivet, L., Horváth, F., and Séranne, M. (Eds.): The Mediterranean basins: Tertiary extension within the Alpine orogen. Integrated Basin Studies Vol. 1., Geological Society, Special Publications, 156, 295-334, 1999.

Fülöp, J., Dank, V., Barabás, A., Bardócz, B., Brezsnyánszky, K., Császár, G., Haas, J., Hámor, G., Jámbor, Á., Sz. Kilényi, É., Nagy, E., Rumpler, J., Szederkényi, T., and Völgyi, L.: Geological map of Hungary without Cenozoic formations. Hungarian Geological Institute, Budapest, 1987.

Fülöp, J. : Introduction to the geology of Hungary. Publishing House of the Hungarian Academy, Budapest, 246 pp., 1989.

Géczy, B.: Plate tectonics and paleogeography in the EastMediterranean Mesozoic. Acta Geologica Acad. Sci. Hung., 17, 421-428, 1973

Gerner, P., Bada, G., Dövényi, P., Müller, B., Oncescu, M. C., Cloetingh, S. A. P. L., and Horváth, F.: Recent tectonic stress and crustal deformation in and around the Pannonian basin: data and models, in: Durand, B., Jolivet, L., Horváth, F., and Séranne, M. (Eds.): The Mediterranean Basins: Tertiary Extension within the Alpine Orogen. Geological Society, London, Special Publications, 156, 1999.

Gúthy, T. and Hegedûs, E.: Age determination of microfaults by high-resolution reflection seismics for seismic hazard investigations. 50th Meeting of European Association of Exploration Geophysicists, The Hague, Abstr. Pap. and Posters, 216, 1988.

Györfi, I., Csontos, L., and Nagymarosy, A.: Early Tertiary structural evolution of the border zone between the Pannonian and Transylvanian basins, in: Durand, B., Jolivet, L., Horváth, F., and Séranne, M. (Eds.): The Mediterranean Basins: Tertiary Extension within the Alpine Orogen. Geological Society, London, Special Publications, 156, 251-267, 1999.

Harding, T. P.: Petroleum traps associated with wrench faults.
Amer. Assoc. Petrol. Geol. Bull., 58, 1290-1304, 1974.

Harding, T. P.: Identification of wrench faults using subsurface structural data: criteria and pitfalls. AAPG Bull, 74, 1590-1609, 1990.

Horváth, F.: Neogene crust evolution of the Great Hungarian Plain and its environment, in: Szederkényi, T. (Ed.): Structural evolution of the basement of the Great Hungarian Plain. Spec. Pub. Hungarian Academy of Science, Szeged, (in Hungarian), 29-35, 1987.

Horváth, F., Czeller, I., Cserny, T., Csontos, L., Dövényi, P., Drahos, D., Gombos, Cs., Gyori, E., Nagymarosy, A., Remete, L., Samu, L., Szabó, A., Székely, B., Tmár, G., Várkonyi, L., Wéber, Z., and Buntebarth, G.: Structural setting of the Paks area on the base of complex interpretation of seismic profiles and further geophysical-geological data. Report on behalf of Nuclear Power Station Ltd., in Paks, 92 pp, 1993.

Horváth, F.: Phases of compression during the evolution of the Pannonian basin and its bearing on hydrocarbon exploration. Marine and Petroleum Geology, Vol. 12, 8, 837-844, 1995.

Horváth, F. and Tari, G.: IBS Pannonian Basin project: a review of the main results and their bearings on hydrocarbon exploration, in: Durand, B., Jolivet, L., Horváth, F., and Séranne, M. (Eds.): The Mediterranean Basins: Tertiary Extension within the Alpine Orogen. Integrated Basin Studies Vol.1., Geological Society, London, Special Publications, 156, 195-213, 1999

Jiricek, R.: Tectogenetic development of the Carpathian arc in the Oligocene and Neogene, in: Machel, M. (Ed.): Tectonic profiles through the West Carpathians. G.U.D.S., Bratislava, 205-214, 1979.

Kázmér, M. and Kovács, S.: Permian-Paleogene paleogeography along the eastern part of the Insubric-Periadriatic lineament system: evidence for continental escape of the Bakony-Drauzug unit. Acta Geol. Hung., 28, 71-84, 1985.

Kilényi, É., Kröll, A., Obernauer, D., Sefara, J., Steinhauser, P. Szabó, Z., and Wessely, G.: Pre-Tertiary basement contour map of the Carpathian basin beneath Austria, Czechoslovakia and Hungary. Geophysical Transactions, 36, 15-36, 1991.

Körössy, L.: The flysch-like formations of the Great Hungarian Basin. Földt. Közl., (in Hungarian), 89(2), 115-124, 1959.

Kőrössy, L.: Flysch formations of Hungary: structural position and connections. Földt. Közl., (in Hungarian), 107(3-4), 398-405, 1977.

Márton, E. and Márton, P.: A refined polar wander curve for the Transdanubian Central Mountains and its bearing on the Mediterranean history. Tectonophysics, 98, 43-57, 1983.

Nagymarosy, A. and Báldi-Beke, M.: The Szolnok unit and its probable paleogeographic position. Tectonophysics, 226, $457-$ 470, 1993.

Pogácsás, Gy., Vakarcs, G., Barvitz, A., and Lakatos, L.: Postrift strike-slip faults in the Pannonian Basin and their role in the hydrocarbon accumulation. Proc 34th Int Geophy Symp, Assoc Hung Geophys, Budapest, vol. II., 601-611, 1989.

Posgay, K., Hegedûs, E., and Tmár, Z.: The identification of mantle reflections below Hungary from deep seismic profiling. Tectonophysics, 173, 379-385, 1990.

Posgay, K. and Szentgyörgyi, K.: Wrench-fault system penetrating the lithosphere in the eastern part of the Pannonian basin. Hungarian Geophysics XXXII., 1-2, 1-15, 1990.

Ratschbacher, L., Frisch, W., Linzer, H. G., and Merle, O.: Lateral extrusion in the Eastern Alps. Part 2: Structural analysis. Tectonics, 10, 257-271, 1991a.

Ratschbacher, L., Merle, O., Davy, Ph., and Cobbold, P.: Lateral 
extrusion in the Eastern Alps. Part 1: Boundary condition and experiments scaled for gravity. Tectonics, 10, 245-256, 1991b.

Rumpler, J. and Horváth, F.: Some representative seismic reflection lines from the Pannonian Basin and their structural interpretation. AAPG Mem 45, 153-170, 1988.

Riedel, W.: Zur Mechanik geologischer Brucherscheinungen: Centralbl. F. Mineral. Geol. u. Pal., v.B, 354-368, 1929.

Sandulescu, M., Krautner, H. G., Balintoni, I., Russo-Sandulescu, D., and Micu, M.: The structure of the East Carpathians, in: Guide to excursion B1: XII Congr Carpatho-Balkan. Geol Assoc., Bucharest, 92 pp., 1981.

Sylvester, A. G.: Strike-slip faults. Geol Soc Am Bull, 100: 16661703, 1988.

Szepesházy, K.: Late Cretaceous and Paleogene Formations in the
Northwestern Part of the Tiszántúl. Academical press, Budapest, (in Hungarian), 96 pp, 1973.

Tari, G.: Neoalpine tectonics of the Danube Basin (NW Pannonian Basin, Hungary), in: Ziegler, P. A. and Horváth, F. (Eds.): PeriTethys Memoir 2, Structure and Prospects of Alpine Basins and Forelands, Editions du Museum Paris, 1996.

Tchalenko, J. S.: Similarities between shear zones of different magnitudes. Geological Society of America Bulletin, 81, 1625-1640, 1970.

Tóth, T. and Horváth, F. . Neotectonic investigation by high resolution seismic profiling, in: Marosi, S. and Meskó, A. (Eds.): Seismic safety of the Paks nuclear power plant. Academical press, Budapest, 123-152, 1997. 